\title{
SOSIALISASI DAMPAK PERNIKAHAN DINI TERHADAP KESEHATAN REPRODUKSI DESA SEMBUNG KECAMATAN NARMADA KABUPATEN LOMBOK BARAT
}

\author{
Alfira Mulya Astuti \\ Dosen Prodi. Matematika, FTK UIN Mataram
}

\begin{abstract}
Abstrak: Pernikahan dini memiliki dampak yang cukup berbahaya bagi yang melakukannya baik pria ataupun bagi wanita, dan dalam berbagai aspek seperti kesehatan, psikologi, dan mental. Walaupun pernikahan usia dini ini memiliki dampak positif, namun dibandingkan dengan faktor negatifnya tentu sangat tidak seimbang. Tersebut merupakan alasan sehingga dilakukannya pengabdian masyarakat di desa Sembung. Adapun fokus pengabdian ini adalah Sosialisasi mengenai dampak pernikahan dini di Desa Sembung Kecamatan Narmada Kabupaten Lombok Barat dengan menghadirkan narasumber dari Pihak Badan Koordinasi Keluarga Berencana Nasional Kota Mataram.

Diawali dengan Sosialisasi mengenai dampak dari pernikahan dini dengan menghadirkan narasumber dari Pusat Studi Gender dan Anak, Bidan yang ditugaskan di Desa Sembung serta salah satu narasumber dari Badan Koordinasi Keluarga Berencana (BKKBN) Kota Mataram. Melakukan pembinaan bagi kaum wanita yang memiliki keterbatasan perekonomian untuk menciptakan suatu yang bermanfaat.

Kesimpulan dari kegiatan ini adalah; pernikahan dini hukumnya sunah bagi yang dapat mengendalikan diri, dan akan menjadi wajib jika antara keduanya sudah tidak dapat mengendalikan dini, menikah dini dalam dua keadaan tersebut bisa mensyaratkan adanya kesiapan ilmu, harta (nafkah) dan fisik, disamping mensyaratkan tetap adanya kemampuan melaksanakan kewajiban menuntut ilmu, islam telah menetapkan hukum - hukum preventif agar para pemuda dan pemudi terhindar dari rangsangan dan godaan untuk berbuat maksiyat seperti zina, Keempat, bahwasanya pernikahan dini itu memiliki dampak positif dan negatif bagi yang melaksanakan, baik ditinjau dari fisik maupun psikisnya.
\end{abstract}

Kata Kunci: Sosialisasi, dampak menikah dini, kesehatan reproduksi

\section{PENDAHULUAN}

Saat ini, pernikahan belum cukup umur ini marak terjadi. Di Indonesia wanita yang berusia 25 sampai 29 tahun yang menikah dibawah usia 18 tahun mencapai $34 \%$, dan Indonesia termasuk dalam lima besar Negara-negara yang persentase pernikahan dini tertinggi di dunia. Berdasarkan usia pernikahan dan level pendidikan, data statistik di Indonesia menunjukkan terdapat $20 \%$ wanita yang menikah di usia sekitar 15-19 tahun dan $18 \%$ wanita yang menikah dengan lakilaki di bawah usia 20 tahun. Pernikahan dini 15-20\% dilakukan oleh pasangan baru, secara nasional pernikahan dini usia pengantin di bawah usia 16 tahun sebanyak $26,9 \%$. 
Pernikahan dini adalah pernikahan yang dilakukan oleh salah satu pasangan yang memiliki usia di bawah umur yang biasanya di bawah 17 tahun. Baik pria atau wanita jika belum cukup umur (17 Tahun) jika melangsungkan pernikahan dapat dikatakan sebagai pernikahan usia dini. Ada banyak faktor negatif dan positif yang harus dihadapi ketika melakukan pernikahan jika belum cukup usia ini. Namun persiapan pernikahan bagi anak di bawah 17 tahun tentu harus diperhatikan sebaik baiknya. Hal ini dikarenakan dapat menyebabkan mental anak menjadi berubah serta kehilangan masa remajanya.

Pernikahan dini memiliki dampak yang cukup berbahaya bagi yang melakukannya baik pria ataupun bagi wanita, dan dalam berbagai aspek seperti kesehatan, psikologi, dan mental. Walaupun pernikahan usia dini ini memiliki dampak positif, namun dibandingkan dengan faktor negatifnya tentu sangat tidak seimbang. Ada berbagai alasan yang menyebabkan terjadinya pernikahan dini, terkadang tidak disengaja atau yang sudah direncanakan, berikut ini adalah beberapa alasannya.

1. Faktor Ekonomi, faktor ekonomi menyebabkan orang tua menikahkan anaknya pada pria/keluarga yang lebih mapan atau hanya untuk mengurangi biaya hidup sehari hari.

2. Perjodohan, mungkin faktor ini sudah sangat kecil yang menyebabkan pernikahan dini, namun beberapa kasus terutama di desa dan kampung, ini masih terjadi.

3. MBA (married by accident), penyebab yang paling banyak terjadinya pernikahan usia dini, terutama terjadi di daerah perkotaan.

4. Cinta sejati, faktor cinta sejati mungkin menjadi alasan terakhir, dimana pasangan ini memang benar-benar mencintai dan ingin segera bersatu.

Pernikahan dini ini memiliki dampak negatif dan dampak positif, namun tentu perlu diketahui pastinya pernikahan usia dini ini sebaiknya dihindari.

Hasil wawancara dengan kepala desa Sembung yang bernama Bukhari beserta Kepala Karang Taruna yang bernama Muhatir Muhammad, S.Pd., memberikan informasi bahwa sebagian besar wanita di desa Sembung menikah di usia dini. Dan terdapat satu dusun di desa Sembung yaitu Dusun Memontong 
dimana Angka Kelahiran sangat besar serta memiliki Kepala Keluarga yang paling banyak. Di Dusun ini pula terjadi paling banyak pernikahan dini.

Uraian di ataslah yang menjadi alasan sehingga memilih desa Sembung sebagai lokasi kegiatan pengabdian. Dengan harapan, setelah memberikan perlakuan berdasarkan rencana kegiatan pengabdian, maka terjadi peminimalisiran Pernikahan dini.

\section{PEMBAHASAN}

\section{Strategi Yang Dilakukan Untuk Mencapai Kondisi Harapan.}

Beberapa metode atau langkah-langkah yang akan diterapkan yaitu: Survei awal yang bertujuan untuk mendapatkan informasi mengenai sumber daya manusia dan non manusia yang dimiliki oleh desa Sembung; Melakukan observasi yaitu melakukan pengamatan langsung terhadap gejala-gejala yang terjadi; Interview (wawancara), yaitu melakukan dialog atau tanya jawab langsung dengan informan yang diperlukan; Pendampingan dan pembinaan dengan kegiatan sosialisasi secara langsung kepada masyarakat (penduduk) dengan mendatangkan narasumber yang relevan.

Instrumen yang digunakan pada kegiatan pengabdian adalah List Dokumentasi serta pedoman wawancara. List dokumentasi digunakan untuk mengecek data-data yang dibutuhkan misalnya data profil desa, dan lain sebagainya. Sedangkan pedoman wawancara digunakan sebagai panduan pertanyaan yang akan diajukan kepada Kepala Desa terkait kondisi masyarakat.

\section{A. Pernikahan Dini}

Pernikahan dalam islam adalah suatu ikatan lahir batin antara seorang laki-laki dengan seorang perempuan untuk hidup bersama dalam rumah tangga yang sakinah, mawadah dan warohmah untuk dapat mempertanhankan hidup dengan menghasilkan keturunan yang dilaksanakan sesuai dengan syariat islam. Seperti dalam QS.Al-Hujurat ayat 13 yang artinya:

"Sesungguhnya Kami menciptakan kamu dari seorang laki-laki dan seorang perempuan dan menjadikan kamu berbangsa-bangsa dan bersuku-suku 
supaya kamu saling kenal mengenal. Sesungguhnya orang yang paling mulia di antara kamu di sisi Allah ialah orang yang paling bertakwa di antara kamu. Sesungguhnya Allah Maha Mengetahui lagi Maha Mengenal ".

Undang-undang negara indonesia juga telah mengatur batas usia perkawinan. Dalam Undang-undang Perkawinan bab II pasal 7 ayat 1 disebutkan bahwa perkawinan hanya diizinkan jika pihak pria mencapai umur 19 (sembilan belas) tahun dan pihak perempuan sudah mencapai umur 16 (enam belas tahun) tahun.

Kebijakan pemerintah dalam menetapkan batas minimal usia pernikahan ini tentunya melalui proses dan berbagai pertimbangan. Hal ini dimaksudkan agar kedua belah pihak benar-benar siap dan matang dari sisi fisik, psikis dan mental. Dari penjelasan diatas dapat disimpulkan bahwa pernikahan dini adalah suatu ikatan yang dilakukan oleh calon wanita dan laklaki disaat usianya masih muda.

\section{B. Faktor-faktor yang Mempengaruhi Pernikahan Dini}

Faktor-faktor yang mempengaruhi pernikahan dini :

1. Faktor tradhisi ( Adat istiadat )

2. Tradhisi (adat istiadat) di lingkungannya yang mayoritas penduduknya menikah saat usianya masih muda.

3. Faktor ekonomi

4. Faktor tingkat pendidikan

5. Faktor hasrat pribadi

6. Faktor Hamil di luar nikah

7. Faktor Pemahaman agama

\section{Hukum Yang Bertalian dengan Menikah Dini}

Menikah dini hakikatnya adalah menikah juga, hanya saja dilakukan oleh mereka yang masih muda dan segar, seperti mahasiswa atau mahasiswi yang masih kuliah atau mereka yang baru lulus SMA. Hukum yang berkaitan dengan nikah dini pada umumnya sama dengan pernikahan biasanya, namun ada pula hal - hal yang memang khusus yang bertolak dari kondisi umum, seperti kondisi mahasiswa yang masih kuliah yang mungkin belum mampu memberi nafkah. 
Hukum umum tersebut yang terpenting adalah kewajiban memenuhi syarat-syarat sebagai persiapan sebuah pernikahan. Kesiapan nikah dalam tinjaun fiqih paling tidak diukur dengan 3 (tiga) hal, yaitu :

a. Pertama, kesiapan ilmu

Yaitu kesiapan tentang pemahaman hukum-hukum fiqih yang berkaitan dengan urusan pernikahan, baik hukum sebelum menikah, seperti hukum khitbah (melamar), pada saat nikah, seperti syarat dan rukun aqad nikah, maupun sesudah nikah, seperti hukum nafkah, thalak, dan ruju`.

b. Kedua, kesiapan materi/harta.

dimaksud harta di sini ada dua macam, yaitu harta sebagai mahar (maskawin) (lihat QS An Nisaa : 4) dan harta sebagai nafkah suami kepada isterinya untuk memenuhi kebutuhan pokok/primer (al hajat al asasiyah) bagi isteri yang berupa sandang, pangan, dan papan (lihat QS Al Baqarah : 233, dan Ath Thalaq : 6). Ketiga, kesiapan fisik/kesehatan.

\section{Dampak Penikahan Dini}

Berbagai dampak pernikahan dini atau perkawinan dibawah umur dapat dikemukakan sebagai berikut :

1. Dampak terhadap hukum, adanya pelanggaran terhadap :

a. UU No. 1 tahun 1974 tentang Perkawinan

Pasal 7 (1) Perkawinan hanya diizinkan jika pihak pria sudah mencapai umur 19 tahun dan pihak wanita sudah mencapai umur 16 tahun.Pasal 6 (2) Untuk melangsungkan perkawinan seorang yang belum mencapai umur 21 tahun harus mendapat izin kedua orang tua.

b. UU No. 23 tahun 2002 tentang Perlindungan Anak

Pasal 26 (1) Orang tua berkewajiban dan bertanggung jawab untuk: mengasuh, memelihara, mendidik dan melindungi anak 1.) menumbuh kembangkan anak sesuai dengan kemampuan, bakat dan minatnya dan; 2.) mencegah terjadinya perkawinan pada usia anak-anak.

c. UU No.21 tahun 2007 tentang PTPPO (Pemberantasan Tindak Pidana Perdagangan Orang. 
Amanat Undang-undang tersebut di atas bertujuan melindungi anak, agar anak tetap memperoleh haknya untuk hidup, tumbuh dan berkembang serta terlindungi dari perbuatan kekerasan, eksploitasi dan diskriminasi. Pemahaman tentang undang-undang tersebut harus dilakukan untuk melindungi anak dari perbuatan salah oleh orang dewasa dan orang tua. Sesuai dengan 12 area kritis dari Beijing Platform of Action, tentang perlindungan terhadap anak perempuan.

2. Dampak biologis

Anak secara biologis alat-alat reproduksinya masih dalam proses menuju kematangan sehingga belum siap untuk melakukan hubungan seks dengan lawan jenisnya, apalagi jika sampai hamil kemudian melahirkan. Jika dipaksakan justru akan terjadi trauma, perobekan yang luas dan infeksi yang akan membahayakan organ reproduksinya sampai membahayakan jiwa anak. Patut dipertanyakan apakah hubungan seks yang demikian atas dasar kesetaraan dalam hak reproduksi antara isteri dan suami atau adanya kekerasan seksual dan pemaksaan (penggagahan) terhadap seorang anak.

3. Dampak Psikologis

Secara psikis anak juga belum siap dan mengerti tentang hubungan seks, sehingga akan menimbulkan trauma psikis berkepanjangan dalam jiwa anak yang sulit disembuhkan. Anak akan murung dan menyesali hidupnya yang berakhir pada perkawinan yang dia sendiri tidak mengerti atas putusan hidupnya. Selain itu, ikatan perkawinan akan menghilangkan hak anak untuk memperoleh pendidikan (Wajar 9 tahun), hak bermain dan menikmati waktu luangnya serta hak-hak lainnya yang melekat dalam diri anak.

4. Dampak Sosial

Fenomena sosial ini berkaitan dengan faktor sosial ekonomi dan budaya dalam masyarakat patriarki yang bias gender, yang menempatkan perempuan pada posisi yang rendah dan hanya dianggap pelengkap seks laki-laki saja. Kondisi ini sangat bertentangan dengan ajaran agama apapun termasuk agama Islam yang sangat menghormati perempuan (Rahmatan lil 
Alamin). Kondisi ini hanya akan melestarikan budaya patriarki yang bias gender yang akan melahirkan kekerasan terhadap perempuan. Untuk faktor sosial ekonomi antara lain remaja harus keluar dari sekolah karena hamil dan harus bekerja, sehingga akan terhambat karirnya.

5. Dampak Perilaku Seksual Menyimpang

Adanya perilaku seksual yang menyimpang yaitu perilaku yang gemar berhubungan seks dengan anak-anak yang dikenal dengan istilah pedofilia. Perbuatan ini jelas merupakan tindakan ilegal (menggunakan seks anak), namun dikemas dengan perkawinan seakan-akan menjadi legal. Hal ini bertentangan dengan UU.No.23 tahun 2002 tentang Perlindungan Anak khususnya pasal $81 .^{8}$

6. Dampak terhadap Kesehatan

Adanya fenomena pernikahan dini yang semakin marak terjadi, hal ini menimbulkan permasalahan yang tidak kalah pentingnya, yaitu peristiwa kehamilan yang terjadi pada wanita usia muda atau yang dikenal dengan istilah kehamilan dini.

Kehamilan adalah masa dimulai dari konsepsi sampai lahirnya janin. Lamanya lahir normal adalah 280 hari (40 minggu atau 9 bulan 7 hari) dimulai dari hari pertama haid terakhir. Kehamilan dibagi dalam 3 triwulan yaitu triwulan pertama dimulai dari konsepsi sampai 3 bulan, triwulan kedua dari bulan keempat sampai 6 bulan, triwulan ketiga dari bulan ketujuh sampai 9 bulan.

Kehamilan dini atau terlalu muda (primi muda) adalah ibu hamil pertama pada usia kurang dari 20 tahun, dimana kondisi panggul belum berkembang secara optimal dan kondisi mental yang belum siap menghadapi kehamilan dan menjalankan peran sebagai ibu.

Persalinan adalah proses di mana bayi, plasenta dan selaput ketuban keluar dari uterus ibu. Persalinan dianggap normal jika prosesnya terjadi pada usia kehamilan cukup bulan (setelah 37 minggu) tanpa disertai adanya penyulit. 
1. Risiko bagi ibunya :

a. Kurangnya Perawatan selama Hamil

Gadis remaja yang hamil terutama jika tidak mendapatkan dukungan dari keluarganya sangat berisiko mengalami kekurangan dalam hal perawatan selama hamil dan sebelum melahirkan. Padahal perawatan ini sangat penting terutama dibulan-bulan awal kehamilan. Perawatan ini berguna untuk memantau kondisi medis ibu dan bayi serta pertumbuhannya, sehingga jika ada komplikasi bisa tertangani dengan cepat.

b. Mengalami perdarahan.

Perdarahan pada saat melahirkan antara lain disebabkan karena otot rahim yang terlalu lemah dalam proses involusi. selain itu juga disebabkan selaput ketuban stosel (bekuan darah yang tertinggal didalam rahim). Kemudian proses pembekuan darah yang lambat dan juga dipengaruhi oleh adanya sobekan pada jalan lahir.

c. Kemungkinan keguguran / abortus.

Keguguran pada usia muda dapat terjadi secara tidak disengaja, misalnya karena terkejut, cemas, stres. Tetapi ada juga keguguran yang sengaja dilakukan oleh tenaga non profesional sehingga dapat menimbulkan akibat efek samping yang serius seperti tingginya angka kematian dan infeksi alat reproduksi yang pada akhirnya dapat menimbulkan kemandulan.

d. Persalinan yang lama dan sulit.

Adalah persalinan yang disertai komplikasi ibu maupun janin.penyebab dari persalinan lama sendiri dipengaruhi oleh kelainan letak janin, kelainan panggul, kelaina kekuatan his dan mengejan serta pimpinan persalinan yang salah

e. Keracunan Kehamilan (Gestosis).

Kombinasi keadaan alat reproduksi yang belum siap hamil dan anemia makin meningkatkan terjadinya keracunan hamil dalam bentuk pre- 
eklampsia atau eklampsia. Pre-eklampsia dan eklampsia memerlukan perhatian serius karena dapat menyebabkan kematian.

f. Kematian Ibu.

Kematian ibu pada saat melahirkan banyak disebabkan karena perdarahan dan infeksi. Selain itu angka kematian ibu karena keguguran juga cukup tinggi karena persalinan kebanyakan dilakukan oleh tenaga non profesional (dukun).

g. Depresi Pasca Melahirkan

Kehamilan yang terjadi pada saat remaja, terlebih yang tidak mendapat dukungan dari suami (yang menghamili) berisiko tinggi mengalami depresi pasca melahirkan. Depresi ini bisa mengganggu perawatan bayi yang baru lahir dan juga perkembangan remaja tersebut ke depannya, karena umurnya yang belasan tahun sudah harus mengurusi anak, ditambah lagi jika dalam pengurusannya tidak ditunjang oleh dukungan suami (bagi remaja yang sudah menikah) dan oleh laki-laki yang menghamili (bagi remaja yang hamil di luar nikah).

h. Resiko Tertular Penyakit Menular Seksual (PMS)

Remaja yang melakukan hubungan seks memiliki risiko tertular penyakit seksual seperti chlamydia dan HIV. Hal ini sangat penting untuk diwaspadai karena PMS bisa menyebabkan gangguan pada serviks (mulut rahim) atau menginfeksi rahim dan janin yang sedang dikandung

i. Anemia Kehamilan

Anemia gizi lebih sering dijumpai dalam kehamilan karena pada masa ini terjadi peningkatan kebutuhan zat-zat makanan untuk mendukung perubahan-perubahan fisiologis selama hamil. Penyebab anemia pada saat hamil diusia muda disebabkan kurang pengetahuan akan pentingnya gizi pada saat hamil di usia muda, karena pada saat hamil mayoritas seorang ibu mengalami anemia. Tambahan zat besi dalam tubuh fungsinya untuk meningkatkan jumlah sel darah merah, 
membentuk sel darah merah janin dan plasenta, lama kelamaan seorang yang kehilangan sel darah merah akan menjadi anemis.

j. Hipertensi

Remaja yang hamil memiliki resiko mengalami tekanan darah tinggi atau disebut dengan pregnancy-induced hypertension, dibandingkan dengan perempuan yang hamil diusia matang. Kondisi ini memicu terjadinya preeklamsia, yaitu kondisi medis berbahaya yang menggabungkan tekanan darah tinggi dengan kelebihan protein dalam urin, pembengkakan tangan dan wajah ibu serta kerusakan organ. Pada pre eklampsia terjadi spasme pembuluh darah disertai dengan retensi garam dan air. Pada biopsi ginjal ditemukan spasme hebat arteriola glomerulus. Pada beberapa kasus, lumen arteriola sedemikian sempitnya sehingga hanya dapat dilakui oleh satu sel darah merah. Jadi jika semua arteriola dalam tubuh mengalami spasme, maka tekanan darah akan naik sebagai usaha untuk mengatasi tekanan perifer agar oksigenasi jaringan dapat dicukupi. Sedangkan kenaikan berat badan dan edema yang disebabkan oleh penimbunan air yang berlebihan dalam ruangan interstitial belum diketahui sebabnya, mungkin karena retensi air dan garam. Proteinuria dapat disebabkan oleh spasme arteriola sehingga terjadi perubahan pada glomerulus (Sinopsis Obstetri).

k. Efek Preeklampsia

Preeklampsia dapat menyebabkan gangguan peredaran darah pada plasenta. Hal ini akan menyebabkan berat badan bayi yang dilahirkan relatif kecil. Selain itu, preeklampsia juga dapat menyebabkan terjadinya kelahiran prematur dan komplikasi lanjutan dari kelahiran prematur yaitu keterlambatan belajar, epilepsi, sereberal palsy, dan masalah pada pendengaran dan penglihatan.

2. Risiko bagi bayinya :

a. Kemungkinan lahir belum cukup usia kehamilan.

Adalah kelahiran prematur yang kurang dari 37 minggu (259 hari). hal ini terjadi karena pada saat pertumbuhan janin zat yang diperlukan berkurang. 
b. Berat badan lahir rendah (BBLR).

Yaitu bayi yang lahir dengan berat badan yang kurang dari 2.500 gram. kebanyakan hal ini dipengaruhi kurangnya gizi saat hamil, umur ibu saat hamil kurang dari 20 tahun. dapat juga dipengaruhi penyakit menahun yang diderita oleh ibu hamil.

c. Cacat bawaan.

Merupakan kelainan pertumbuhan struktur organ janin sejak saat pertumbuhan. Hal ini dipengaruhi kurangnya pengetahuan ibu tentang kehamilan, pengetahuan akan asupan gizi rendah, kelainan genetik dan kromosom, infeksi, virus rubella, pemeriksaan kehamilan (ANC) kurang, keadaan psikologi ibu kurang stabil. Selain itu cacat bawaan juga di sebabkan karena keturunan (genetik) proses pengguguran sendiri yang gagal, seperti dengan minum obat-obatan (gynecosit sytotec) atau dengan loncat-loncat dan memijat perutnya sendiri.

d. Kematian bayi.

kematian bayi yang masih berumur 7 hari pertama hidupnya atau kematian perinatal yang disebabkan berat badan kurang dari 2.500 gram, kehamilan kurang dari 37 minggu (259 hari), kelahiran kongenital serta lahir dengan asfiksia.

Agar risiko berkurang, ada beberapa hal yang sebaiknya dilakukan ibu dan keluarga jika hamil pertama di usia rawan, yaitu

1. Konsultasikan kehamilan pada ahlinya.

Karena ibu yang hamil di usia rawan memerlukan pengawasan khusus selama kehamilan dan pada proses persalinan. Sebaiknya ibu ditangani dokter spesialis dan bukan bidan atau dokter umum. Bila kondisi tidak memungkinkan, setidaknya ibu pernah satu- dua kali berkonsultasi dengan dokter spesialis agar mendapat pemeriksaan yang khusus dan teliti, seperti pemeriksaan panggul, tekanan darah dan pemeriksaan USG.

2. Proses persalinan sebaiknya dilakukan di rumah sakit dengan fasilitas yang memenuhi standar. 
Rumah sakit yang tidak memiliki NICU (Neonatal Intensive Care Unit) tentu tak dapat memberikan fasilitas yang memadai bagi bayi yang lahir prematur. Padahal risiko ini bisa terjadi pada ibu yang hamil di usia rawan. Sarana dan prasarana yang baik juga berguna bila terjadi suatu kelainan pada proses persalinan, misalnya ibu mengalami perdarahan.

3. Berkonsultasi dengan ahli gizi.

Terutama untuk ibu yang hamil di usia sangat muda. Umumnya, pengetahuan kehamilan yang dimiliki masih kurang sehingga pola makannya pun kurang baik, misalnya meskipun hamil dia tetap mengonsumsi junk food. Di sinilah ahli gizi berperan membimbing pola makannya agar menjadi lebih baik. Pola makan yang baik dapat menghindari anemia, hipertensi dan diabetes pada ibu hamil.

4. Lakukan tes amniosentesis pada awal kehamilan bagi wanita berusia 35 tahun atau lebih pada kehamilan pertama untuk menemukan kemungkinan sindrom down dan abnormalitas kromosom lain.

5. Penuhi konsumsi 0,4 miligram asam folat setiap hari selama 3 bulan sebelum kehamilan (pada kehamilan yang direncanakan). Bila tidak, asam folat bisa diberikan pada 3 bulan pertama kehamilan untuk mengejar ketinggalan kebutuhannya.

6. Lakukan aktivitas untuk menjaga kondisi fisik selama hamil.

Senam hamil pun sangat disarankan untuk mempelancar proses persalinan.

Selain berdampak pada kesehatan kehamilan dan persalinan, juga berdampak pada kesehatan reproduksi. Pada masa remaja ini, alat reproduksinya belum matang untuk melakukan fungsinya. Rahim (uterus) baru siap melakukan fungsinya setelah umur 20 tahun, karena pada masa ini fungsi hormonal melewati masa yang maksimal. Pada usia 14-18 tahun, perkembangan otot-otot rahim belum cukup baik kekuatan dan kontraksinya sehingga jika terjadi kehamilan rahim dapat rupture (robek). Pada usia 14-19 tahun, sistem hormonal belum stabil, kehamilan menjadi tidak stabil mudah terjadi pendarahan dan terjadilah abortus atau kematian 
janin. Usia kehamilan terlalu dini dari persalinan memperpanjang rentang usia reproduksi aktif. Hal ini dapat mengakibatkan resiko kanker leher rahim dikemudian hari.

Remaja yang menikah dini baik secara fisik maupun biologis belum cukup matang untuk memiliki anak, sehingga kemungkinan anak cacat dan anak ataupun ibu meninggal saat proses persalinan lebih tinggi. Pernikahan dini juga berisiko mengakibatkan penyakit kanker mulut rahim dan rasa sakit pada kemaluan wanita saat beruhubungan intim. Perempuan yang menikah dibawah umur 20 tahun beresiko terkena kanker leher rahim. Pada usia remaja, sel-sel leher rahim belum matang. Kalau terpapar human papiloma virus atau HPV pertumbuhan sel akan menyimpang menjadi kanker. Leher rahim ada dua lapis epitel, epitel skuamosa dan epitel kolumner. Pada sambungan kedua epitel terjadi pertumbuhan yang aktif, terutama pada usia muda. Epitel kolumner akan berubah menjadi epitel skuamosa. Perubahannya disebut metaplasia. Kalau ada HPV menempel, perubahan menyimpang menjadi displasia yang merupakan awal dari kanker. Pada usia lebih tua, di atas 20 tahun, sel-sel sudah matang, sehingga resiko makin kecil. Gejala awal perlu diwaspadai, keputihan yang berbau, gatal serta perdarahan setelah senggama. Jika diketahui pada stadium sangat dini atau prakanker, kanker leher rahim bisa diatasi secara total. Untuk itu perempuan yang aktif secara seksual dianjurkan melakukan tes Papsmear 2-3 tahun sekali (Apriliana, 2011)

\section{E. Upaya Penanggulangan Dampak Penikahan Dini}

Upaya penanggulangan resiko tinggi pernikahan dini menurut Sibagariang (2010), adalah sebagai berikut :

1. Pencegahan

Orang tua perlu manyadari bahwa pernikahan dini bagi anaknya penuh dengan resiko yang membahayakan baik secara sosial, kejiwaan maupun kesehatan. Remaja putri perlu diberikan informasi tentang hak-hak reproduksinya dan resiko pernikahan dini. Bagi remaja yang belum menikah, kehamilan remaja dapat dicegah dengan cara menghindari terjadinya senggama, itu berarti remaja harus mengisi waktunya dengan kegiatan-kegiatan yang akan memberi bekal hidupnya dimasa depan. 
2. Penanganan

Kehamilan remaja merupakan kehamilan yang beresiko karena itu remaja yang hamil harus intensif memeriksakan kehamilannya. Dengan demikian diharapkan kelainan dan penyulit yang akan terjadi dapat segera diobati.

\section{F. Faktor-faktor yang Mempengaruhi Pengetahuan Remaja Tentang Dampak Pernikahan Dini Pada Kesehatan Reproduksi}

1. Informasi

Menurut Soetjiningsih (2004) bahwa faktor yang menjadi sebab terjadinya pengetahuan yang kurang tentang masalah remaja terutama tentang pernikahan dini yaitu institusi pendidikan langsung yaitu guru sekolah dan orang tua yang kurang siap memberikan informasi yang kurang dan tepat waktu. Semakin maju tehknologi, membaiknya komunikasi mengakibatkan membanjirnya arus informasi dari luar yang sulit sekali diseleksi. Informasi adalah keterangan pemberitahuan kabar berita dari suatu media dan alat (sarana) komunikasi seperti koran, majalah, radio, televisi, poster, spanduk, internet, dan tenaga kesehatan. Media komunikasi adalah media yang digunakan pembaca untuk mendapatkan informasi sesuatu atau hal tentang pengetahuan. Berkaitan dengan penyediaan informasi bagi manajemen dalam pengambilan keputusan, informasi yang diperoleh harus berkaitan. Kualitas informasi tergantung tiga hal yaitu akurat, tepat waktu dan relevan. (Tugiman, 2006).

Seseorang di dalam proses pendidikan juga memperolah pengetahuan melalui berbagai macam alat bantu. Alat bantu media akan membantu dalam melakukan penyuluhan. Agar pesan kesehatan dapat disampaikan dengan jelas dengan media orang dapat lebih mengerti fakta kesehatan yang dianggap rumit sehingga mereka dapat menghargai betapa bernilainya kesehatan (Notoatmodjo, 2003). Kriteria informasi baik jika mendapatkan informasi $\geq 6$ media, dan cukup jika mendapatkan informasi < dari 6 media (Notoatmodjo, 2005). 
Transformasi, Vol. 13, No. 1, Januari 2017: 92 - 108

\section{Peran Orang Tua}

Orang tua merupakan tempat anak berlindung dan mendapatkan kedamaian melalui keserasian antara ketertiban dan ketrentraman dengan mempertimbangkan pengaruh-pengeruh yang datang dari luar rumah, tidaka ada pihak lain yang dapat menggantikan peranan orang tua dengan seutuhnya. Keberhasilan orang tua di dalam menunjang motivasi dan keberhasilan studi terletak pada eretnya hubungan orang tua dengan anaknya (Soekanto, 2007).

\section{Suasana dan Kondisi (Rekam Proses)}

Kegiatan pengabdian masyarakat dengan tema sosialisasi dampak pernikahan dini bagi kesehatan berjalan dengan lancar. Acara diawali dengan pembukaan dan pemberian sambutan dalam hal ini dilakukan oleh Pengabdi, ibu Alfira Mulya Astuti, M.Si. Kegiatan sosialisasi dibuka secara resmi oleh Kepala Desa, Bapak Bukhari.

Para narasumber menyampaikan materi secara bergantian. Diawali oleh Ibu Nikmatullah, MA yang menyampaikan materi tentang gambaran umum pernikahan dini dan dilanjutkan oleh ibu Lia Lestari Widiyanti, A.Md.Keb yang menyampaikan materi terkait dampak pernikahan dini terhadap kesehatan. Setiap narasumber diberikan waktu masing-masing 45 menit untuk menyampaikan materi.

Sesi berikutnya setelah penyampaian materi adalah sesi tanya jawab (diskusi). Pada kegiatan ini, peserta sangat antusias. Karena terbatasnya waktu, maka peserta dibatasi untuk memberikan pertanyaan. Adapun pertanyaan yang diajukan peserta adalah :

1. Pertanyaan ditujukan kepada ibu Nikmatullah, M.A. "Salah satu dampak negatif dari terjadinya pernikahan dini adalah munculnya kekerasan dalam rumah tangga. Pertanyaan saya adala Apakah penyebab kekerasan dalam rumah tangga tersebut? "

Penanya : Saudari Aspurniawati (17 Tahun) berasal dari Sembung Barat.

2. Pertanyaan ditujukan kepada ibu Lia Lestari Widiyanti, A.Md.Keb. Bagaimana mengatasi Insomnia?

Penanya: Saudara Nizarul Izomi (18 Tahun) berasal dari dusun Jejelok. 
Pertanyaan yang diajukan oleh peserta dijawab langsung oleh para narasumber. Adapun jawaban para narsumber adalah :

1. Penyebab kekerasan dalam rumah tangga atau yang biasa dikenal dengan KDRT diantaranya adanya komunikasi yang kurang efektif antara pasangan suami dan istri.

2. Terdapat bentuk-bentuk KDRT yang selama ini tidak disadari oleh masyarakat, misalnya kekerasan ekonomi (tanpa adanya pemberian nafkah).

3. Cara mengatasi insomnia adalah terlebih dahulu dengan memahami penyebab insomnia. Dimana penyebab insomnia beragam. Setelah tahu barulah bisa mengatasinya. Banyak cara yang bisa digunakan yaitu: Olahraga secara teratur, Mengatur pola makan, Jika ada masalah, jangan dipendam sendiri. Berbagilah dengan orang yang dipercayakan

Sesi setelah diskusi adalah penutup. Kegiatan sosialisasi ditutup dengan pembacaan doa oleh salah satu mahasiswa peserta KKP IAIN Mataram Kelompok 16 yang bernama Misbahul Ardi. Selama pelaksanaan kegiatan sosialisasi, pengabdi berperan sebagai fasilitator dan mendampingi pelaksanaan kegiatan hingga akhir.

\section{PENUTUP}

Kesimpulan yang dapat ditarik dari pelakasanaan kegiatan ini adalah :

1. Pertama, pernikahan dini hukumnya sunah bagi yang dapat mengendalikan diri, dan akan menjadi wajib jika antara keduanya sudah tidak dapat mengendalikan dini.

2. Kedua, menikah dini dalam dua keadaan tersebut bisa mensyaratkan adanya kesiapan ilmu, harta (nafkah) dan fisik, disamping mensyaratkan tetap adanya kemampuan melaksanakan kewajiban menuntut ilmu.

3. Ketigat, islam telah menetapkan hukum - hukum preventif agar para pemuda dan pemudi terhindar dari rangsangan dan godaan untuk berbuat maksiyat seperti zina.

4. Keempat, bahwasanya pernikahan dini itu memiliki dampak positif dan negatif bagi yang melaksanakan, baik ditinjau dari fisik maupun psikisny. 
Transformasi, Vol. 13, No. 1, Januari 2017: 92 - 108

\section{DAFTAR PUSTAKA}

Alfiyah, Hukum Pernikahan

Dini.

http://alfiyah23.student.umm.ac.id/category/hukum-pernikahan-dini/ diakses 20 Oktober 2016

Dampak pernikahan dini : perkawinan di bawah umur. http://alfiyah23.student.umm.ac.id/2010/01/29/dampak-pernikahandini/ diakses 20 Oktober 2016

Amelia, F. Gambaran tingkat pengetahuan remaja putri terhadap resiko perkawinan dini usia 14- 20 tahun pada kehamilan dan proses persalinan. Jakarta : Stikes Bhakti Pertiwi Indonesia, 2011.

Murcahya, A., Dinamika psikologis pengambilan keputusan untuk menikah dini. Surakarta : Universitas Muhamadiyah Surakarta, 2010.

Nurya, T. 2016. Resiko kehamilan pada usia dini (primi muda). http://nursecarewithlove.blogspot.com/2011/09/resiko-kehamilan-pada-usia-diniprimi.html , diakses 20 Oktober 2016

Sastrawinata, U S., Gambaran epidemiologi klinik kehamilan remaja di RS Immanuel Bandung. JKM. Volume 7, 2007.

Sarwono, IImu Kebidanan. Jakarta : Yayasan Bina Pustaka Sarwono Prawirohardjo, 2005.

Surya, K W., Penyesuaian pernikahan remaja putri yang melakukan pernikahan dini. Sumatera Utara : Universitas Sumatera Utara, 2007.

UNICEF, Early marriage : a harmful traditional practice. The United Nations Children's Fund (UNICEF), 2005. 